\title{
Mechanisms Contributing to the Phase-Dependent Regulation of Neurogenesis by the Novel Antidepressant, Agomelatine, in the Adult Rat Hippocampus
}

\author{
Amélie Soumier', Mounira Banasr', Sylviane Lortet', Frédérique Masmejean', Nathalie Bernard', \\ Lydia Kerkerian-Le-Goff', Cecilia Gabriel' ${ }^{2}$, Mark J Millan ${ }^{3}$, Elisabeth Mocaer² and Annie Daszuta*,', \\ I'IC2N, IBDML, UMR 6216, Marseille, France; ${ }^{2}$ IRIS, Courbevoie, France; ${ }^{3}$ IDR Servier, Croissy-sur-Seine, France
}

\begin{abstract}
Agomelatine is a novel antidepressant acting as a melatonergic receptor agonist and serotonergic $\left(5-\mathrm{HT}_{2} \mathrm{C}\right)$ receptor antagonist. In adult rats, chronic agomelatine treatment enhanced cell proliferation and neurogenesis in the ventral hippocampus $(\mathrm{VH})$, a region pertinent to mood disorders. This study compared the effects of agomelatine on cell proliferation, maturation, and survival and investigated the cellular mechanisms underlying these effects. Agomelatine increased the ratio of mature vs immature neurons and enhanced neurite outgrowth of granular cells, suggesting an acceleration of maturation. The influence of agomelatine on maturation and survival was accompanied by a selective increase in the levels of BDNF (brain-derived neurotrophic factor) vs those of VEGF (vascular endothelial factor) and IGF-I (insulin-like growth factor I), which were not affected. Agomelatine also activated several cellular signals (extracellular signal-regulated kinase I/2, protein kinase B, and glycogen synthase kinase $3 \beta$ ) known to be modulated by antidepressants and implicated in the control of proliferation/survival. Furthermore, as agomelatine possesses both melatonergic agonist and serotonergic (5- $\mathrm{HT}_{2 \mathrm{C}}$ ) antagonist properties, we determined whether melatonin and $5-\mathrm{HT}_{2} \mathrm{C}$ receptor antagonists similarly influence cell proliferation and survival. Only the 5- $\mathrm{HT}_{2 \mathrm{C}}$ receptor antagonists, SB243,213 or S32006, but not melatonin, mimicked the effects of agomelatine on cell proliferation in $\mathrm{VH}$. The promoting effect of agomelatine on survival was not reproduced by the $5-\mathrm{HT}_{2 \mathrm{C}}$ receptor antagonists or melatonin alone. However, it was blocked by a melatonin antagonist, S22153. These results show that agomelatine treatment facilitates all stages of neurogenesis and suggest that a joint effect of melatonin agonism and $5 \mathrm{HT}_{2} \mathrm{C}$ antagonism may be involved in promotion by agomelatine of survival in the hippocampus.

Neuropsychopharmacology (2009) 34, 2390-2403; doi: I 0. I038/npp.2009.72; published online I July 2009
\end{abstract}

Keywords: antidepressant; 5- $\mathrm{HT}_{2 \mathrm{C}}$ receptor; melatonin; trophic factors; cell signaling; rat

\section{INTRODUCTION}

Adult neurogenesis occurs in the dentate gyrus (DG) of the hippocampus of a large number of mammalian species, including humans (Eriksson et al, 1998). 'Neurogenesis' refers to a series of developmental steps including proliferation, differentiation and maturation, and it is a prerequisite for the development of fully functional neurons (Song et al, 2002). This long and complex process can abort at each one of these critical phases, complicating the study of the functional roles of new neurons and underpinning the importance of understanding the mechanisms involved in each step of cellular generation and survival. Although the implication of altered hippocampal neurogenesis in the pathogenesis of depression remains to be clarified (Kempermann et al, 2008), cell proliferation and neurogenesis are generally reduced in

*Correspondence: Dr A Daszuta, UMR 6216, Luminy Scientific Campus, Case 907, 13288 Marseille Cedex 09, France, Tel: + 33 491269250, Fax: + 33 491269244, E-mail: daszuta@ibdml.univ-mrs.fr Received 5 February 2009; revised 20 May 2009; accepted 6 June 2009 animal models of depression and increased by chronic antidepressant treatments (Warner-Schmidt and Duman, 2006). Furthermore, the reduced efficacy of antidepressants for exerting their behavioral effects in animals in which hippocampal neurogenesis has been compromised by irradiation suggests an important role of neurogenesis in the expression of anxiolytic-antidepressant-like properties of antidepressant agents (Santarelli et al, 2003; Jiang et al, 2005). There are also more recent reports indicating that the implication of neurogenesis in the behavioral effects of antidepressants may depend on the type of drug and its mode of action (Surget et al, 2008; Sahay and Hen, 2007). This explains increasing interest in new antidepressants, such as agomelatine (Kennedy, 2007), and in the molecular mechanisms underlying their influence on cellular neuroplasticity and adult neurogenesis. Accumulating evidence supports a role of trophic factors and related signaling cascades in the behavioral and neurogenic effects of antidepressants. This neurotrophic hypothesis of antidepressant actions is based on observations that antidepressants stimulate growth factors such as brain-derived neurotrophic factor (BDNF), 
insulin-like growth factor (IGF-1) and/or vascular endothelial growth factor (VEGF) expression (Schmidt and Duman, 2007; Warner-Schmidt and Duman, 2007). These growth factors generally enhance adult neurogenesis and may exert behavioral antidepressant-like effects (Jin et al, 2002; Anderson et al, 2002; Khawaja et al, 2004; Malberg and Blendy, 2005; Schechter et al, 2005; Schmidt and Duman, 2007). Related to the modulation of trophic factors action, antidepressants and mood stabilizers regulate the activity of signal-transduction pathways, such as the extracellular signal-regulated kinase (ERK), protein kinase B (AKT), and glycogen synthase kinase $3 \beta$ (GSK $3 \beta$ ) cascades, which are strongly implicated in synaptic plasticity, response to stress, and induction of mood disorders (Manji et al, 2003; Duman et al, 2007).

Agomelatine is a novel antidepressant possessing melatonergic receptor agonist (MT1 and MT2) (Audinot et al, 2003) and $5-\mathrm{HT}_{2 \mathrm{C}}$ receptor antagonist properties (Millan et al, 2003), which displays robust antidepressant and anxiolytic-like actions in preclinical models (Papp et al, 2003; Millan et al, 2005) and alleviates various symptoms of major depression in humans (Loo et al, 2002; Kennedy and Emsley, 2006; Olié and Kasper, 2007; Dubocovich, 2006). Interestingly, both under basal and stressful conditions, agomelatine enhances hippocampal neurogenesis in rats (Maccari S, unpublished data; Banasr et al, 2006), with a distinctive profile in that it (1) selectively increases cell proliferation and neurogenesis in the ventral hippocampus $(\mathrm{VH})$, a region connected with limbic structures, such as the amygdala, the prefrontal cortex and the nucleus accumbens, and strongly implicated in the response to stress (Bannerman et al, 2004), and (2) enhances the survival of newly generated cells throughout the entire hippocampus. Furthermore, agomelatine enhances hippocampal cell proliferation only after chronic (21 days), but not acute ( $4 \mathrm{~h}$ ) or subchronic (8 days) administration (Banasr et al, 2006). This influence of agomelatine on adult neurogenesis in a specific subterritory of the hippocampus provides an insight into the possible functional implication of adult neurogenesis in the control of affective disorders and may also be an instructive model for investigating the cellular mechanisms involved in the effects of antidepressants on cell proliferation and survival, respectively.

Accordingly, using in vivo and in vitro approaches in combination with confocal analysis and multiple labeling of cells, this study characterized the influence of chronic agomelatine treatment on the phenotypic/morphologic maturation of newly formed granule cells and their survival over time. We also compared the regional influence of agomelatine with the effects of melatonin and those of the selective 5- $\mathrm{HT}_{2 \mathrm{C}}$ receptors antagonists, SB242,084, SB243,213, and S32006, upon hippocampal cell proliferation (bromodeoxyuridine (BrdU) injected the day after the last drug administration) and survival ( $\mathrm{BrdU}$ injected before the first drug administration). Indeed, we have previously shown that various 5-HT receptor subtypes are involved in the regulation of adult neurogenesis and $5-\mathrm{HT}_{2 \mathrm{C}}$ receptors have a selective influence depending on the neurogenic zones (Banasr et al, 2004). Here, we further specified the agomelatine's action on cell survival by examining the effect of a pretreatment with a melatonin receptor antagonist (S22153). Moreover, using western blots and ELISA techniques, we explored the effects of agome- latine on trophic factors (BDNF, VEGF, and IGF-1 proteins) and intracellular signaling pathways (ERK1/2, AKT, and GSK3 $\beta$ ), involved in the control of proliferation and neuronal survival. Because $5-\mathrm{HT}_{2 \mathrm{C}}$ receptors per se have been implicated in the pathogenesis and treatment of anxiety and depression (Millan, 2005), we also examined the effects of the $5-\mathrm{HT}_{2 \mathrm{C}}$ receptor antagonists on BDNF, VEGF, and IGF-1 levels, as well as cell signaling pathways. Finally, the effects of melatonin on BDNF were also evaluated.

\section{MATERIALS AND METHODS}

\section{Animals and Drug Treatments}

Seven-week-old male Wistar rats (Charles River, France) were group-housed under standard conditions (12-h light/ dark cycle, $20 \pm 2{ }^{\circ} \mathrm{C}$, food and water ad libitum). All procedures were conducted in accordance with the French Agriculture and Forestry Ministry (decree 87848, license 01498). SB242,084, a selective $5-\mathrm{HT}_{2 \mathrm{C}}$ receptor neutral antagonist (Kennett et al, 1997), SB243,213, a selective $5-\mathrm{HT}_{2 \mathrm{C}}$ receptor inverse agonist (Wood et al, 2001), and S32006, a novel 5- $\mathrm{HT}_{2 \mathrm{C}}$ receptor inverse agonist (Dekeyne et al, 2008), were injected once a day, at $10 \mathrm{mg} / \mathrm{kg}$ i.p. dissolved in sterile water or $1 \%$ hydroxyethylcellulose (HEC). Doses of 5- $\mathrm{HT}_{2 \mathrm{C}}$ antagonists were selected on the basis of the well-characterized actions of these drugs in functional studies performed both in our laboratory and elsewhere (Di Matteo et al, 1999; Kennett et al, 1997; Wood et al, 2001; Dekeyne et al, 2008). Agomelatine was injected as a suspension in $1 \% \mathrm{HEC}$ at $40 \mathrm{mg} / \mathrm{kg}$ i.p. once a day for 8 , 15 , or 21 days, and melatonin was injected as a suspension in $1 \% \mathrm{HEC}$ at $40 \mathrm{mg} / \mathrm{kg}$ i.p. once a day for 21 days. The choice of agomelatine and melatonin doses was made on the basis of their activity at this range of dose in animal models of depression and anxiety (Papp et al, 2003; Millan et al, 2005), and on neurogenesis (Banasr et al, 2006). S22153, an MT1/MT2 receptor antagonist (Weibel et al, 1999), dissolved in $1 \%$ HEC was injected at $10 \mathrm{mg} / \mathrm{kg}$ i.p. $15 \mathrm{~min}$ before each agomelatine administration (once a day for 15 days). All drugs were provided by IRIS (Institut de Recherches Internationales Servier, France), except melatonin (Sigma-Aldrich), and injected at 17:00. For cell proliferation study, BrdU (200 mg/kg i.p.) was administered $2 \mathrm{~h}$ before perfusion. For cell maturation and survival studies, animals received five injections of BrdU $(75 \mathrm{mg} / \mathrm{kg}$, 2-h intervals) the first day of treatment and were killed 8, 15 , or 21 days later.

\section{Immunohistochemistry and Quantification}

Anaesthetized animals with chloral hydrate were transcardially perfused with $4 \%$ paraformaldehyde (PFA) in $0.1 \mathrm{M}$ phosphate-buffered saline ( $\mathrm{pH}$ 7.4). Serial coronal sections through the rostro-caudal hippocampal extent were collected and treated as reported (Banasr et al, 2006). For BrdU staining, we used a monoclonal mouse anti-BrdU $(1: 200$; Dako, France, $\left.48 \mathrm{~h}, 4{ }^{\circ} \mathrm{C}\right)$, a biotinylated goat anti-mouse secondary antibody (1:200; Dako; $2 \mathrm{~h} \mathrm{RT}$ ) followed by amplification (Elite $\mathrm{ABC}$ Kit, Vector) and diaminobenzidine vizualization method. The BrdU-labeled cell quantification was performed as described (Banasr et al, 2006). 
The BrdU-labeled cells present in the subgranular zone and in the granule cell layer of the DG were examined in the dorsal-rostral (interaural $6.20-3.70 \mathrm{~mm}$ ) and the ventralcaudal (interaural $3.70-2.28 \mathrm{~mm}$ ) part of the hippocampus (Paxinos and Watson, 1986).

For multiple labeling, sections were incubated with mouse anti-NeuN (1:1000; Chemicon, France), rabbit anti- GFAP (1:500; Dako), mouse anti-PSA-NCAM, (1/500, AbCys, France) for $48 \mathrm{~h}$ at $4{ }^{\circ} \mathrm{C}$ and exposed to respective secondary antibodies: Alexa Fluor 633 goat anti-mouse, Alexa Fluor 546 goat anti-rabbit, and Alexa Fluor 594 goat anti-mouse $(1: 200$, Molecular Probes, France; $2 \mathrm{~h} \mathrm{RT}$ ). PSA-NCAM is a marker of neuroplasticity (Gascon et al, 2007) and when coexpressed with BrdU, it labels committed neuronal precursors in adult neurogenic niches (Ming and Song, 2005). Sections were then incubated with rat anti-BrdU ( $1: 100$; Jackson, France) followed by incubation with Alexa Fluor 488 donkey anti-rat antibody (1:100; Jackson, France; $2 \mathrm{~h}$ RT). The BrdU-positive cells co-labeled with GFAP, NeuN, and PSA-NCAM were visualized with a confocal scanning laser microscope, in $z$ axis with a $0.5 \mu \mathrm{m}$ step. The percentage of co-expression was determined in the dorsal hippocampus (DH) and VH (25 cells randomly picked in each region per rat).

\section{ELISA and Western Blot Analyses}

Animals were killed by decapitation and hippocampi were dissected out and stored at $-80^{\circ} \mathrm{C}$ until use. Tissue samples were homogenized at $4{ }^{\circ} \mathrm{C}$ in Promega lysis buffer $(137 \mathrm{mM}$ $\mathrm{NaCl} ; 20 \mathrm{mM}$ Tris- $\mathrm{HCl}, \mathrm{pH}$ 8.0; $1 \% \mathrm{NP} 40 ; 10 \%$ glycerol) for ELISA and in EBM lysis buffer $(0.20 \mathrm{mM}$ Tris- $\mathrm{HCl}, \mathrm{pH} 7.5$; $150 \mathrm{mM} \mathrm{NaCl}$, $5 \mathrm{mM}$ EGTA, $5 \mathrm{mM}$ EDTA, 10\% glycerol, $1 \%$ Triton X-100) supplemented with phosphatase inhibitors (Halt phosphatase inhibitor cocktail from Pierce) for western blots. Both lysis buffers were supplemented with protease inhibitors cocktail (Roche). Samples were then sonicated and lysates were cleared by centrifugation at $4{ }^{\circ} \mathrm{C}$, $15000 \mathrm{~g}$. Protein concentrations were determined according to the Bradford assay using bovine serum albumin as standard. Quantifications of VEGF and IGF-1 proteins were measured with Quantikine $M$ mouse VEGF and IGF-1 enzyme immunoassay kits (R\&D Systems) and BDNF protein with a mouse ELISA kit (Emax $\mathrm{R}$ immunoAssay System, Promega). ERK, AKT, and GSK3 phosphorylation was studied on samples diluted in loading buffer (Tris- $\mathrm{HCl}$ $0.3 \mathrm{M}$, pH6.8; 4\% SDS; $50 \%$ glycerol; dithiothreitol $0.5 \mathrm{M}$ ). Proteins $(50 \mu \mathrm{g})$ were resolved by SDS-polyacrylamide gel and blotted onto nitrocellulose membranes. Immunodetection was carried out with mouse anti-phospho-ERK1/2 $(1: 2000$; Cell Signaling Technology, CST), rabbit antiphospho-AKT ( $1: 1000$; CST), rabbit anti-phospho-GSK3 $\alpha \beta$ (1:1000; CST), rabbit anti-ERK1/2 (1:1000, CST), rabbit anti-AKT ( $1: 1000$; CST), and rabbit anti-GSK3 $\beta$ ( $1: 1000$; CST). Antibodies against actin or tubulin (Sigma) were used to control for equal protein loading. Bands were visualized by enhanced chemiluminescence (ECL kit from Pierce) and quantified using Image $J$ software. Immunoreactivity of each sample was then normalized to the amount of actin or tubulin and expressed as a percentage of the value obtained in the vehicle-treated animals.

\section{Hippocampal Primary Culture and Morphometric Analyses}

To target the peak of granule cells ontogenesis (Altman and Bayer, 1990), hippocampi were obtained from 4-day-old Wistar rat pups. Pooled hippocampi were mechanically triturated, suspended in Neurobasal-A medium supplemented with $2 \%$ heat-inactivated fetal calf serum and plated at 300000 cells $/ \mathrm{ml}$ on poly-L-ornithin (10\%) precoated coverslips. After $24 \mathrm{~h}$, the entire medium was replaced with Neurobasal-A medium supplemented with $2 \%$ B-27 and an antibiotic mixture of penicillin $(50 \mathrm{U} / \mathrm{ml})$ and streptomycin $(50 \mu \mathrm{g} / \mathrm{ml})$ (GIBCO, Invitrogen). Cultures were maintained at $37^{\circ} \mathrm{C}$ in a humidified $5 \% \mathrm{CO}_{2}$ atmosphere and daily treated with various concentrations of agomelatine $\left(10^{-8}\right.$, $10^{-7}$, and $10^{-6} \mathrm{M}$ ) or vehicle for 8 days. Agomelatine was diluted in alcohol $\left(10^{-1} \mathrm{M}\right)$ and then in culture medium up to final concentrations.

Cultures were fixed in $4 \%$ PFA, incubated with $3 \%$ bovine serum albumin (Sigma-Aldrich) and overnight incubated at $4{ }^{\circ} \mathrm{C}$ with mouse anti-nestin (1:1000, Chemicon), rabbit anti-GFAP (1:500, Dako), mouse anti-MAP-2 (1/250, Sigma-Aldrich), and rabbit anti-Prox-1 (1/2000, Abcys). Prox 1 is a transcription factor allowing the detection of new granule neurons in the DG (Pleasure et al, 2000; Brandt et al, 2003). Double labeling was performed with Alexa Fluor 488- and 546- goat and rabbit antibodies $(1: 1000$, Molecular Probes). Nuclear counterstaining was performed using DAPI (0.001\%, Sigma-Aldrich). Labeled cells were counted with a fluorescent microscope in five-six randomly chosen fields on two dishes per experimental condition, from three independent cultures. Total dendritic length and branching point numbers per cell were measured on 100 Prox1-MAP-2 co-labeled cells per dish and experimental condition using Neurite Outgrowth from the Metamorph software.

\section{Statistical Analyses}

Data are means \pm SEM (5-7 animals per group). For cell proliferation and survival studies, analyses on the number of BrdU-labeled cells in the $\mathrm{DH}$ and $\mathrm{VH}$ were performed using two-way ANOVA (region $\times$ drug treatment). Analysis of cell maturation was performed with a two-way ANOVA (phenotype $\times$ drug treatment). For the other studies, statistical analyses were performed with one-way ANOVA followed by Holm-Sidak's test for multiple comparison procedures. The level of statistical significance was set at $p<0.05$.

\section{RESULTS}

\section{Agomelatine Increases Cell Maturation In Vivo and In Vitro}

The degree of maturation of newly formed cells labeled with BrdU in vivo was determined at 8 and 15 days of development, using a combination of PSA-NCAM and NeuN labeling to assess different stages of neuronal maturation. At 8 days, under control conditions, the majority of BrdU-labeled cells expressed PSA-NCAM only (Figure 1a). PSA-NCAM-NeuN co-expression was 
detected in $10 \%$ of BrdU-labeled cells, while almost no new neurons $(0.2 \%)$ expressing NeuN only were detected. Consistent with the transient expression of PSA-NCAM (Seki, 2002), a $42 \%$ decrease in the number of PSANCAM-labeled cells excluding NeuN was observed at 15 days, associated with a threefold increase in the number of cells co-expressing PSA-NCAM and NeuN (Figure 1a and $b$ ). When compared with the vehicle-treated group at 8 days, agomelatine induced a small but significant decrease in the number of PSA-NCAM cells $(9 \%$; $p<0.05)$, mirroring the increase in PSA-NCAM-NeuN co-labeled cells $(8 \% ; p<0.05)$, and it did not influence
NeuN expression (Figure 1a). At 15 days, agomelatine induced also a decrease in the proportion of PSA-NCAMlabeled cells $(11 \% ; p<0.01)$ and an increase in the number of NeuN cells $(7 \% ; p<0.05)$, while no significant difference was observed in the proportion of cells colabeled by PSA-NCAM and NeuN (Figure 1b). As illustrated in the pie-chart (Figure 1c) showing the percentages of all BrdU cell types, including unidentified ones, agomelatine produced a shift in differentiation leading to a highly significant increase in the number of mature neurons, which was doubled as compared with control values $(p<0.01)$.
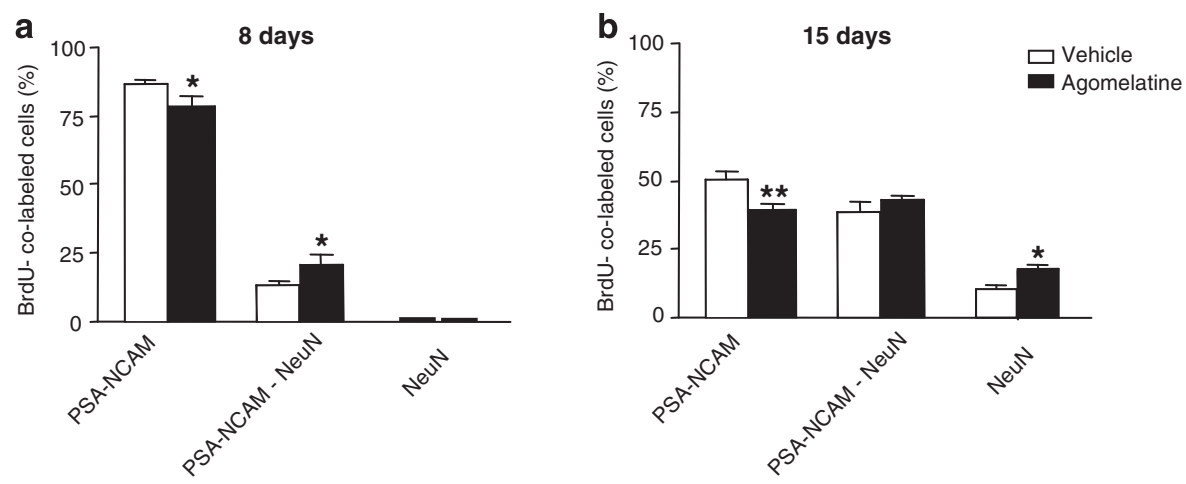

C Percentages of BrdU cell types detected after 15 days of agomelatine treatment
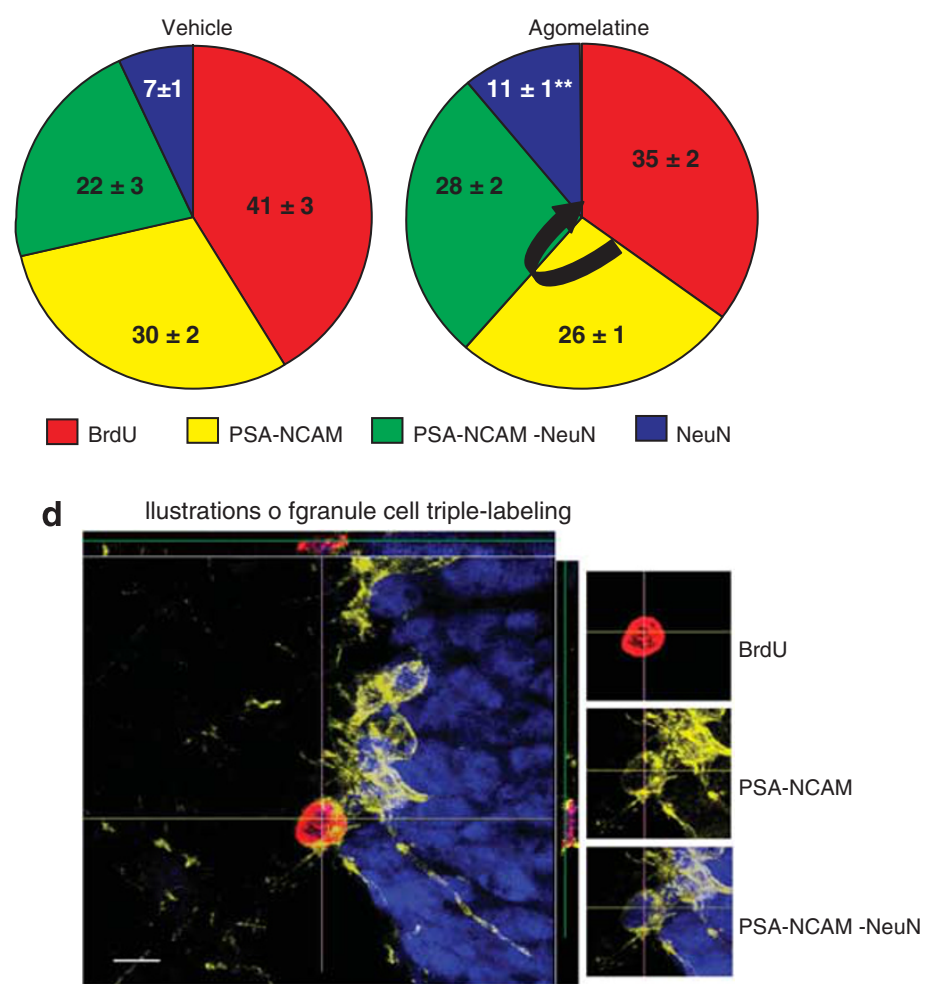

Figure I Agomelatine treatment accelerates the phenotypic maturation of newborn granule cells in vivo. Ratios of different cell types were estimated at different stages of development using confocal microscopy and multiple labeling of markers selective for immature (PSA-NCAM) and mature neurons (NeuN). Same studies were performed at 8 (a) and 15 days (b) after BrdU injection and compared between agomelatine- vs vehicle-treated rats. Bar graphs show decreases in percentage of newborn cells labeled with PSA-NCAM only and corresponding increases in more mature (PSA-NCAM/NeuN) and NeuN only labeled cells, over time. Results are presented as means \pm SEM of number of BrdU-co-labeled cells (two-way ANOVA, *p $<0.05$, *** $<0.0$ I vs vehicle). (c) The pie-chart graphs show the distribution of all BrdU cell types, including unidentified BrdU cells, at 15 days and the shift toward more mature neurons. Results are means \pm SEM of percentages expressed relative to BrdU cells for $n=6-8$ rats by group (two-way ANOVA, * $p<0.05$, *** $p<0.0$ I vs vehicle) (d) Illustration of a BrdU cell co-labeled with PSA-NCAM and NeuN (arrow). Scale bar: $10 \mu$. 
To study the effect of agomelatine on morphological maturation, we developed a postnatal hippocampal culture relatively enriched in granule cells as identified by Prox1 labeling (Pleasure et al, 2000). At DIV 8, postnatal hippocampal cultures contained a majority of neural progenitor cells identified by Nestin expression $(41 \%$ of DAPI-labeled cells; Figure 2), and rather similar proportions of astrocytes detected using GFAP (21\% of DAPIlabeled cells; Figure 2) and neurons either detected by MAP-2 (18\% of DAPI-labeled cells) or Prox1, representing the granule cell population (5\% of DAPI-labeled cells; Figure 2). Although the morphologies of GFAP- and Nestin-labeled cells are rather close, we found few double-labeled cells. All Prox1-labeled cells expressed MAP-2 and represented about $20 \%$ of this population. At this developmental stage, Prox1MAP-2 co-labeled cells were characterized by small roundovoid cell bodies (about $10-\mu \mathrm{m}$ in diameter) and unipolar primary dendritic trees (Figure 2). Exposure to various concentrations of agomelatine for 8 days did not affect the total number of MAP-2-labeled cells, whereas $10^{-7} \mathrm{M}$ agomelatine significantly increased the number of Prox1MAP-2-labeled cells $(46 \% ; p<0.05)$ (Figure $3 \mathrm{a}$ and $\mathrm{b})$. A tendency toward an increase was also observed at $10^{-8} \mathrm{M}$, whereas there was no effect at the highest dose of $10^{-6} \mathrm{M}$. Moreover, agomelatine did not affect the number of GFAPlabeled cells (data not shown). Using the Neurite Outgrowth module of Metamorph software, we could trace and quantify the dendritic profile of each Proxl granule neuron (Figure $3 \mathrm{c}, \mathrm{d}$ and e). Under control conditions, the mean neurite length of granule neurons was around $110 \mu \mathrm{m}$, which was increased by 35 and $38 \%$ in cultures treated with $10^{-8}$ and $10^{-7} \mathrm{M}$ agomelatine, respectively $(p<0.01$, Figure 3c). The number of branching points per granule neuron was also increased at agomelatine concentrations of $10^{-8} \mathrm{M} \quad(28 \%, p<0.05)$ and $10^{-7} \mathrm{M} \quad(47 \%, p<0.05)$
(Figure 3d). Agomelatine $\left(10^{-6} \mathrm{M}\right)$ had no effect on neurite length or the number of branching points.

\section{Agomelatine Increases Cell Survival In Vivo}

As antidepressant effects on neurogenesis depend on the duration of treatment, we first determined the time course of cell survival following 8, 15, and 21 days of agomelatine administration (Figure 4). Under control condition, the mean number of BrdU cells/DG decreased significantly between 8 and 15 days post-BrdU injections (two-way ANOVA, time $\times$ region, $p<0.05$ ). When compared with the vehicle-treated (control) group, agomelatine had no effect at 8 days in the $\mathrm{DH}$ or $\mathrm{VH}$, but it produced significant increases in the number of BrdU-labeled cells in both regions after 15 or 21 days administration. We thus used the 15 or 21 days administration for the next experiments on cell survival.

We then compared the effects of 21 days administration of agomelatine, melatonin, and $5-\mathrm{HT}_{2 \mathrm{C}}$ receptor antagonists on cell survival. Only agomelatine produced significant increases in both the $\mathrm{DH}$ and $\mathrm{VH}$ (23 and 33\%, respectively, $p<0.05)$, whereas SB243,213, S32006, SB242,084, and melatonin had no effect (Figure $5 \mathrm{c}$ and $\mathrm{d}$ ). These changes led to similar increases in newly formed neurons or astrocytes, as shown by the confocal microscopy analyses revealing no effect of agomelatine on the respective percentages of BrdU-NeuN- vs BrdU-GFAP-labeled cells neither in the $\mathrm{DH}$ nor in the $\mathrm{VH}$ (Table 1). As melatonin has been implicated in hippocampal cell survival (Kong et al, 2008; Quiros et al, 2008; Manda et al, 2009; Ramirez-Rodriguez et al, 2009), we tried to show a possible implication of melatonin agonist properties in the effect of agomelatine by adding a melatonin inhibitor together with agomelatine. We found that the daily pretreatment with the
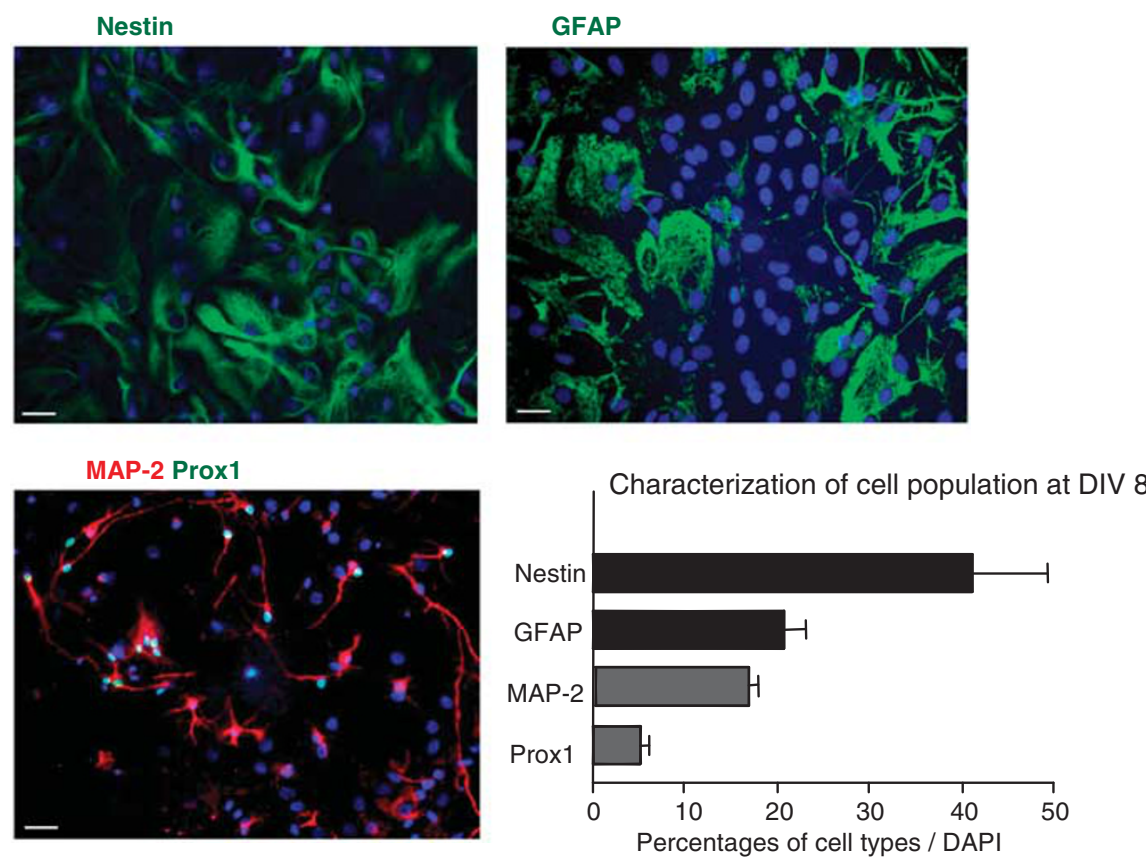

Figure 2 Cellular characterization of postnatal (P4) hippocampal cultures at 8 days in vitro (DIV 8). Neural progenitor cells, astrocytes, and neurons were detected with Nestin, GFAP, and MAP-2 antibodies, respectively. Granular cells were identified with Proxl expression. Results are expressed as a percentage of DAPI-labeled cells (blue) in three independent experiments. Scale bar: $50 \mu$. 
a

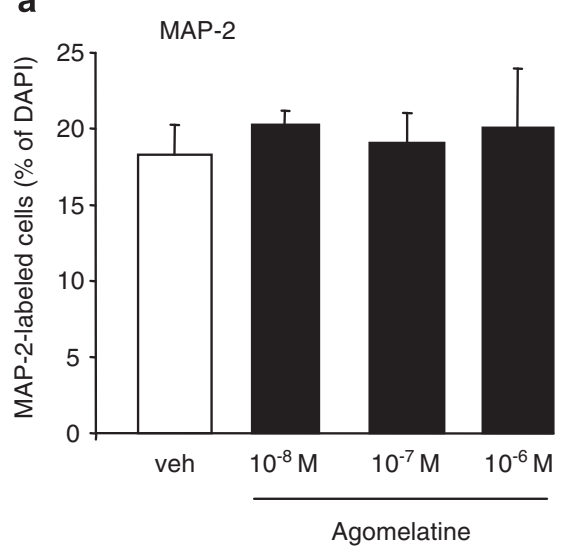

C

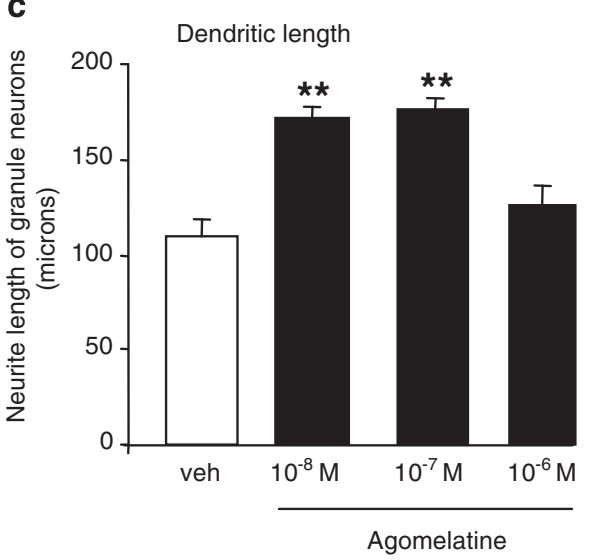

e
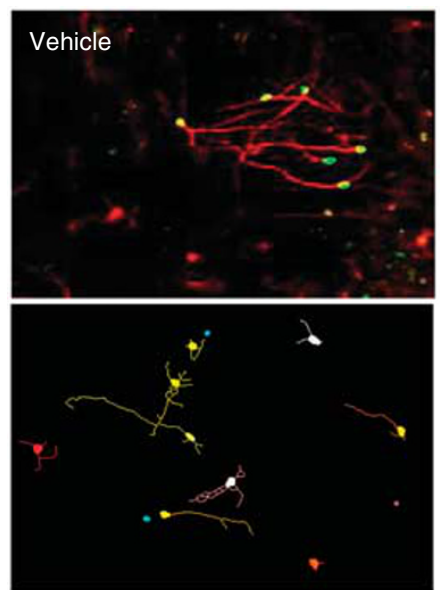

b

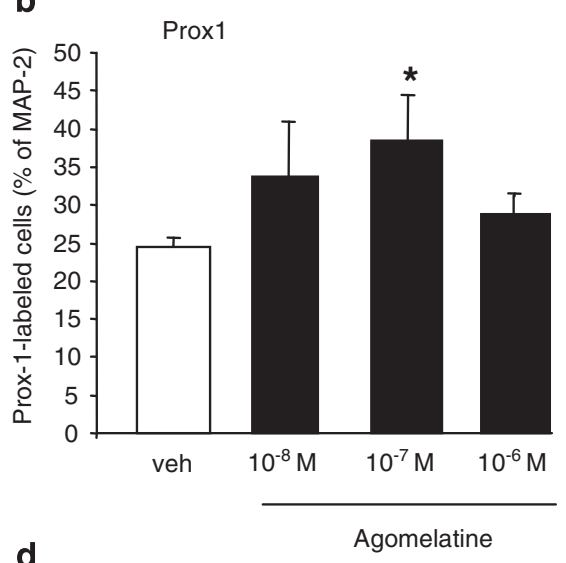

d
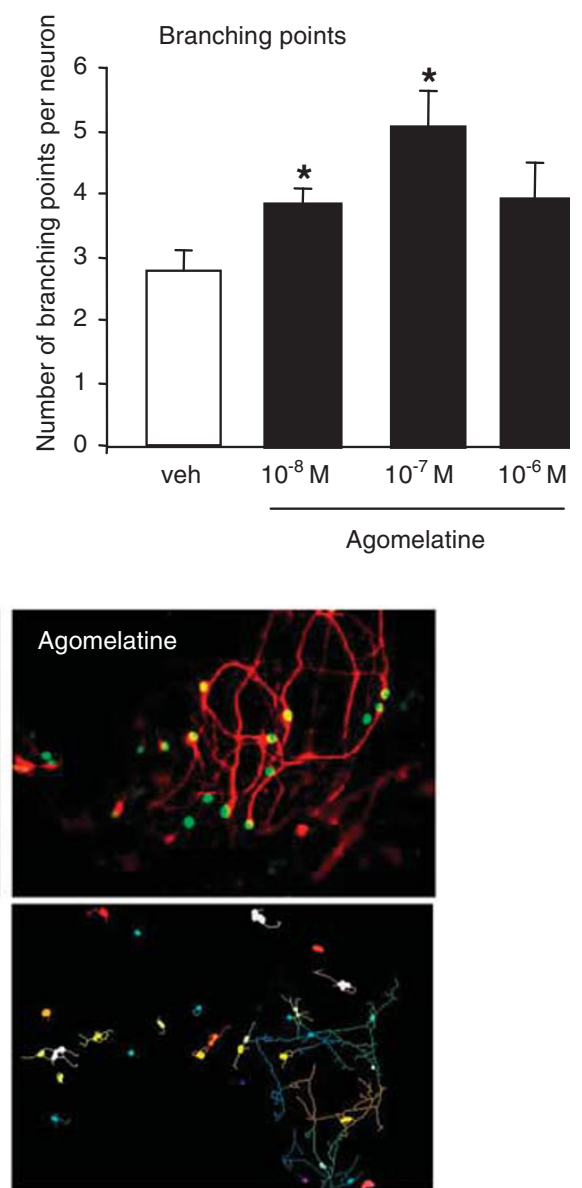

Figure 3 Agomelatine treatment increases the morphologic maturation of granule cells in vitro. Quantifications of MAP-2 (a) and Prox I-labeled (b) cells in postnatal hippocampal cultures at DIV 8 treated with various concentrations of agomelatine $\left(10^{-8}, 10^{-7}\right.$, and $\left.10^{-6} \mathrm{M}\right)$ or vehicle. Agomelatine treatment did not affect the number of MAP-2 cells (a) and increased the percentage of Proxl cells (b), their dendritic length (c), and number of branching points (d). Results are means \pm SEM of the percentage of DAPI (a) or MAP-2-labeled cells (b). Metamorph software was used to measure dendritic length and branching points per granule neuron expressed as means \pm SEM (c, d). Representative examples of ProxI-MAP2 cells in vehicle- and agomelatine (I $0^{-7}$ M)treated cultures, analyzed with Metamorph software (e). Cells were analyzed in three independent experiments for each condition (ANOVA * $p<0.05$; *** $p<0.0$ I vs vehicle). Scale bar: $50 \mu$.

melatonin antagonist, S 22153, just before agomelatine administration abolished the agomelatine effect on cell survival at 15 days post-BrdU injection. Indeed, the mean number \pm SEM of BrdU cells of treated rats in both subregions (DH: $777 \pm 62$; VH: $547 \pm 24$ ) was not any more different from control (DH: $767 \pm 45$; VH: $487 \pm 47$ ).

\section{Agomelatine Increases Cell Proliferation In Vivo}

The effects of agomelatine, melatonin, and 5-HT2C antagonists were also compared with cell proliferation after 21 days of treatment. We corroborated our previous study (Banasr et al, 2006), showing that agomelatine induced a 

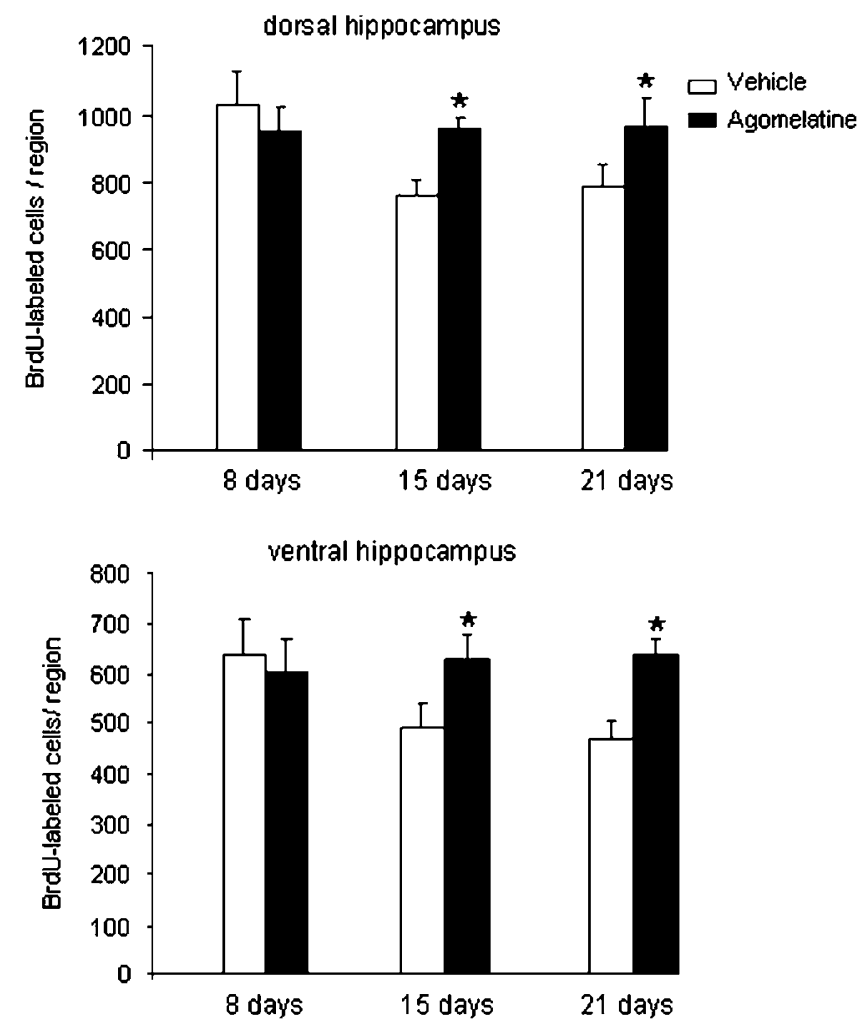

Figure 4 Time course analysis of cell survival. Hippocampal BrdUlabeled cells were quantified after 8, 15, or 21 days of agomelatine treatment $(40 \mathrm{mg} / \mathrm{kg}$ i.p.). BrdU was injected the first day of treatment. Results are means \pm SEM of the number of BrdU-labeled cells per region quantified in the dorsal and ventral GCL for $n=7-8$ rats per group (twoway ANOVA *p $<0.05$ vs vehicle).

$39 \%$ increase $(p<0.05)$ in the percentage of BrdU-labeled cells in the $\mathrm{VH}$, whereas the DH was not affected (Figure 5a and $\mathrm{b}$ ). The $5-\mathrm{HT}_{2 \mathrm{C}}$ receptor antagonists (inverse agonists), S32006 and SB242,313, also produced significant increases in cell proliferation in the $\mathrm{VH}(30 \%, p<0.05$ and $42 \%$, $p<0.01$, respectively) without affecting the $\mathrm{DH}$ (Figure $5 \mathrm{a}$ and b). In contrast, SB242,084 (a neutral antagonist) was ineffective (Figure 5a and b). Melatonin induced no significant change in cell proliferation in either the $\mathrm{VH}$ or the $\mathrm{DH}$ (Figure $5 \mathrm{a}$ and $\mathrm{b}$ ).

\section{Agomelatine has Selective Effect on BDNF Level and Stimulates ERK1/2, AKT, and GSK3 $\beta$ Cell Signaling Pathways}

Changes in hippocampal BDNF, VEGF, and IGF-1 levels were examined after chronic (21 days) agomelatine treatment. ELISA analyses performed in hippocampal tissue extracts $16 \mathrm{~h}$ after the last drug administration showed that agomelatine treatment induced significant increases in the whole hippocampal BDNF level $(28 \% ; p=0.02$; agomelatine group: $32.4 \pm 1.3$; control group: $25.3 \pm 0.8 \mathrm{pg} / \mathrm{mg}$ prot.) but produced no change in VEGF or IGF-1 levels. Quantifications of trophic factors were performed separately on the $\mathrm{DH}$ and $\mathrm{VH}$ to search for a possible regional effect that could have been masked in the global analysis However, no regional change was observed for VEGF or IGF1, while agomelatine induced significant increases in BDNF level both in the $\mathrm{DH}$ and $\mathrm{VH}$ (37 and $19 \%$ respectively, $p<0.05$ ) (Figure 6).

The effects of chronic agomelatine administration on the level of phosphorylation of ERK1/2, AKT, and GSK3 $\beta$ in hippocampal tissue, $16 \mathrm{~h}$ after the last drug injection were also examined. Although no change was observed in total protein levels in any case, a twofold increase in ratios of P-ERK1/2 to ERK1/2 $(p<0.01)$, and 30 and $57 \%$ increases for ratios of $\mathrm{P}-\mathrm{AKT}$ to $\mathrm{AKT}$ and of $\mathrm{P}-\mathrm{GSK} 3 \beta$ to $\mathrm{GSK} 3 \beta$, respectively $(p<0.05)$ were detetected in agomelatinetreated rats (Figure 7 ).

\section{Effects of 5-HT2C Receptor Antagonists on Trophic Factors and Cell Signaling Pathways}

To test a potential implication of $5-\mathrm{HT}_{2 \mathrm{C}}$ receptors in agomelatine-induced changes in neurogenesis by trophic factors, we also measured BDNF, VEGF, and IGF-1 levels in hippocampal tissue after chronic (21 days) administration of SB242,084 or SB243,213, but did not find any significant effect (Table 2).

With regard to cell signaling pathways (Figure 8), these treatments induced significant increases in the level of phosphorylation of ERK1/2 (33 and 34\%, respectively; $p<0.05)$. By contrast, decreases in the level of phosphorylation of AKT and GSK3 $\beta$ were detected in hippocampal tissue obtained from rats treated with SB243,213 (21 and $29 \%$, respectively; $p<0.05)$.

\section{Effect of Melatonin on BDNF Level}

We also examined the consequences of 21 days treatment with melatonin on hippocampal level of BDNF. Compared with agomelatine treatment, melatonin induced a smaller increase at the limit of significance $(17 \% ; p=0.05)$ in hippocampal BDNF level (melatonin group: $29.6 \pm 0.5$; control group: $25.3 \pm 0.8 \mathrm{pg} / \mathrm{mg}$ prot.).

\section{DISCUSSION}

The present experiments show that agomelatine influences various phases of adult hippocampal neurogenesis, including cell proliferation, maturation, and survival, with distinctive patterns of action. Our data suggest a role for $5-\mathrm{HT}_{2 \mathrm{C}}$ receptor blockade in the regulation of cell proliferation in the $\mathrm{VH}$, whereas control of cell survival throughout the whole hippocampus depends upon the joint action of agomelatine at both types of receptors. Furthermore, the results also suggest that recruitment of BDNF and the ERK and AKT-GSK $3 \beta$ signaling pathways participate in the induction of hippocampal neurogenesis by agomelatine.

\section{Agomelatine Selectively Increases Cell Proliferation in VH: Possible Mediation By 5-HT $2 \mathrm{c}$ Receptors}

The selective agomelatine-induced increase in cell proliferation in the $\mathrm{VH}$ is of particular interest with regard to the anatomical and functional differences between the VH (temporal pole) and DH (septal pole) (Moser and Moser, 1998; Bannerman et al, 2004). The projections of the $\mathrm{VH}$ to the prefrontal cortex and its strong connection with the amygdala support the view that 
a

Proliferation

dorsal hippocampus

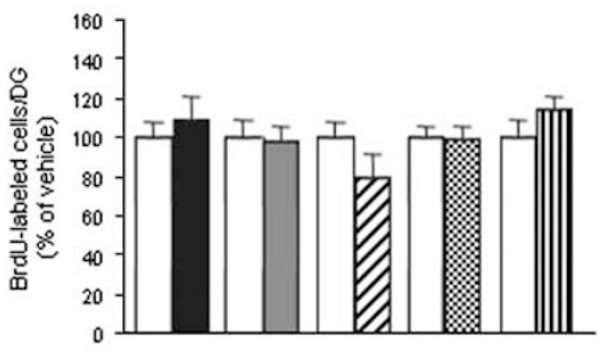

b

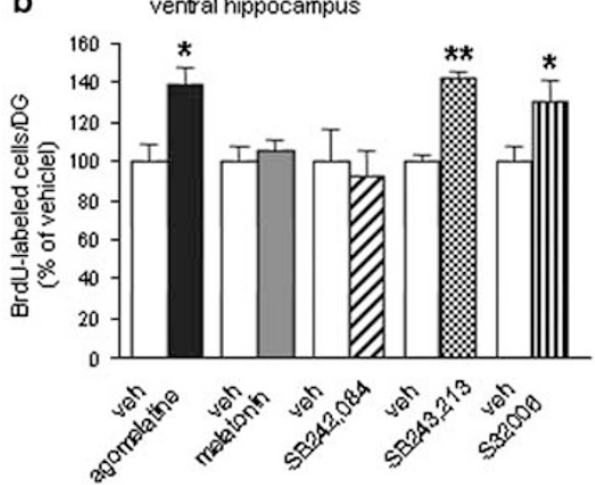

c

Survival

dorsal hippocampus

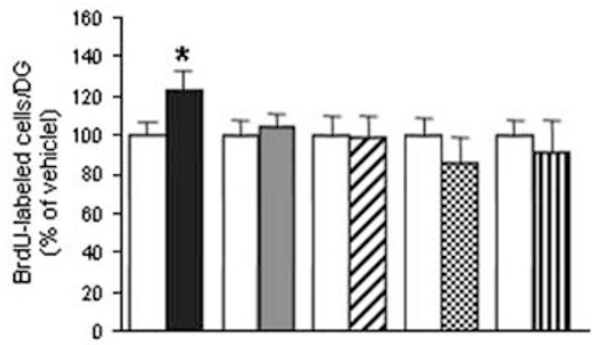

d ventral hippocampus

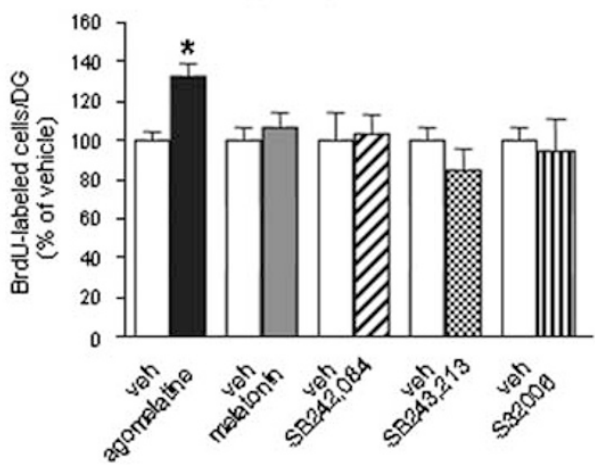

Figure 5 Comparative effects of agomelatine, melatonin, and 5- $\mathrm{HT}_{2 \mathrm{C}}$ receptor antagonists on cell proliferation and survival after $2 \mathrm{I}$ days treatment. BrdU was injected either at the end (proliferation) or beginning (survival) of drug treatments. BrdU-labeled cells were quantified in the SGZ (proliferation), or GCL (survival) both in the dorsal (a, c) and ventral (b, d) hippocampus. Rats were treated once daily with agomelatine or melatonin (40 mg/kg i.p., each) or various $5-\mathrm{HT}_{2 \mathrm{C}}$ receptor antagonists (10 mg/kg i.p.). Treatment with agomelatine, SB243,213, and S32006 selectively increased cell proliferation in the ventral hippocampus, whereas an increase in cell survival was observed only after agomelatine treatment in the ventral and dorsal hippocampus. Results are means \pm SEM of the number of BrdU-labeled cells expressed as a percentage of respective controls, for $n=6-8$ rats per group (two-way ANOVA ${ }^{*} p<0.05$, *** $p<0.0$ I vs vehicle).

Table I Percentages of BrdU Cells Co-expressing NeuN or GFAP

\begin{tabular}{|c|c|c|c|c|c|c|}
\hline & \multicolumn{2}{|c|}{ BrdU unidentified } & \multicolumn{2}{|c|}{ BrdU/NeuN } & \multicolumn{2}{|c|}{ BrdU/GFAP } \\
\hline & Dorsal & Ventral & Dorsal & Ventral & Dorsal & Ventral \\
\hline Vehicle & $32 \pm 3$ & $34 \pm 4$ & $65 \pm 3$ & $63 \pm 4$ & $3 \pm 2$ & $3 \pm 1$ \\
\hline Agomelatine & $37 \pm 4$ & $37 \pm 5$ & $62 \pm 4$ & $61 \pm 6$ & $3 \pm 1$ & $2 \pm 1$ \\
\hline
\end{tabular}

Daily administrations of agomelatine or vehicle given for 21 days and starting with BrdU injection did not change the ratio neuron (NeuN)/glia (GFAP) Results are means $\pm \mathrm{SEM}$ of BrdU-labeled cells expressed in percentages, quantified in the GCL of the dorsal and ventral hippocampus (25 cells per rat, each) for five rats per group.

the $\mathrm{VH}$ is particularly involved in 'emotional circuitry' and more specialized for the control of anxiety and depressionrelated functions, whereas the $\mathrm{DH}$ is more implicated in cognitive functions (Bannerman et al, 2004; Engin and Treit, 2007). Although this regional dissociation regarding the implication of new neurons in learning and memory processes is not so simple (Snyder et al, 2008), several studies showed selective decreases in neurogenesis in the $\mathrm{VH}$ following various stress exposures, which elicit depressive-like behavior in adult rat (Kim et al, 2005; Jayatissa et al, 2006; Lagace et al, 2006). Moreover, prenatal stress induced a selective reduction in neurogenesis in the $\mathrm{VH}$ associated with anxious behavior and reversed by agomelatine treatment (Maccari S, unpublished data). These results further suggest that this regional stimulatory effect of agomelatine on cell proliferation is not mediated by melatonin receptors, but rather by the blockade of $5-\mathrm{HT}_{2 \mathrm{C}}$ receptors. Indeed, two different $5-\mathrm{HT}_{2 \mathrm{C}}$ receptor antagonists, SB243,213 and S32006 (Wood et al, 2001; Dekeyne et al, 2008), mimicked agomelatine's effect on cell proliferation in the VH only. In line with these observations, it has also been demonstrated that $5-\mathrm{HT}_{2 \mathrm{C}}$ receptor-binding sites are more densely expressed in the VH compared with DH (Holmes et al, 1995). Interestingly, the anxiolytic properties of agomelatine principally reflect acute blockade of 5- $\mathrm{HT}_{2 \mathrm{C}}$ receptors (Millan et al, 2005), and $5-\mathrm{HT}_{2 \mathrm{C}}$ receptors located in the $\mathrm{VH}$ are specifically involved in the response to anxiety (Alves et al, 2004). Altogether, these data reinforce the hypothesis of a functional dissociation in neurogenesis between hippocampal subregions that may be related to how hippocampal circuit dynamics underlie affective disorders (Meltzer et al, 2005; Airan et al, 2007).

Intriguingly, in contrast to SB243,213 and S32006, another antagonist, SB242,084 administered at a functionally equivalent dose, failed to induce proliferation in the $\mathrm{VH}$. One factor which may account for this difference is that SB242,084 consistently behaves as a neutral antagonist at unedited, wild-type 5- $\mathrm{HT}_{2 \mathrm{C}}$ receptors, whereas SB243,203 and S32006 are essentially inverse agonists (Kennett et al, 

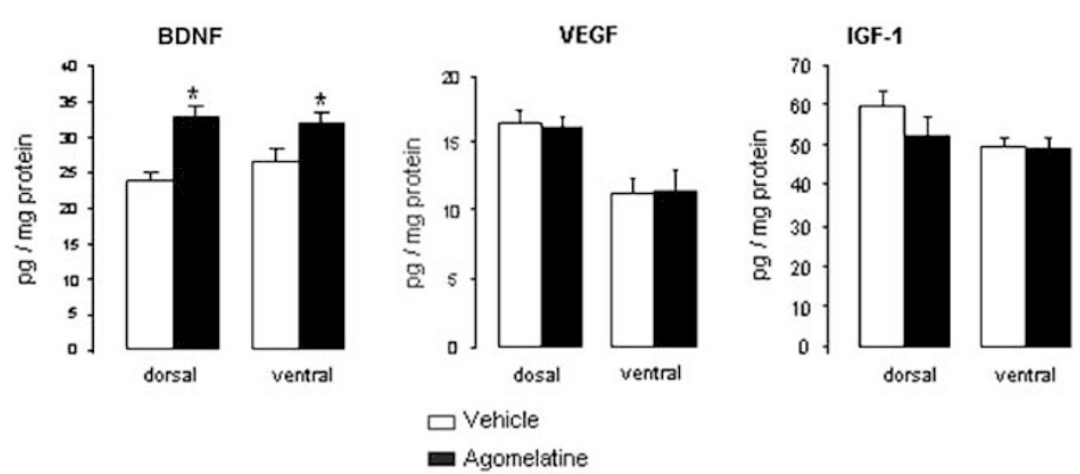

Figure 6 Effects of agomelatine treatment on trophic factor levels in the hippocampus. Levels of VEGF, IGF-I, and BDNF protein were measured in the dorsal and ventral hippocampus $16 \mathrm{~h}$ after the last vehicle or agomelatine treatment (2I days, $40 \mathrm{mg} / \mathrm{kg}$ i.p.). Hippocampal extracts were analyzed by ELISA assays. Results are means \pm SEM pg/mg total protein for six rats per group (ANOVA $* p<0.05$ vs vehicle).

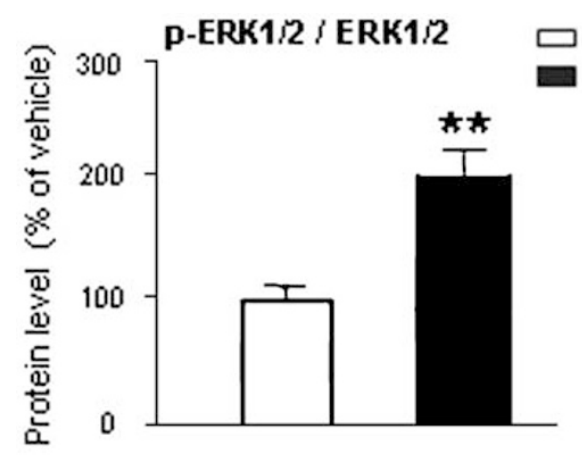

Whicle

Agomelatine

p-ERK1/2

$\mathrm{ERK} 1 / 2$

Tubulin

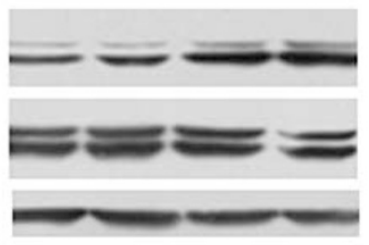

VEH

AGO
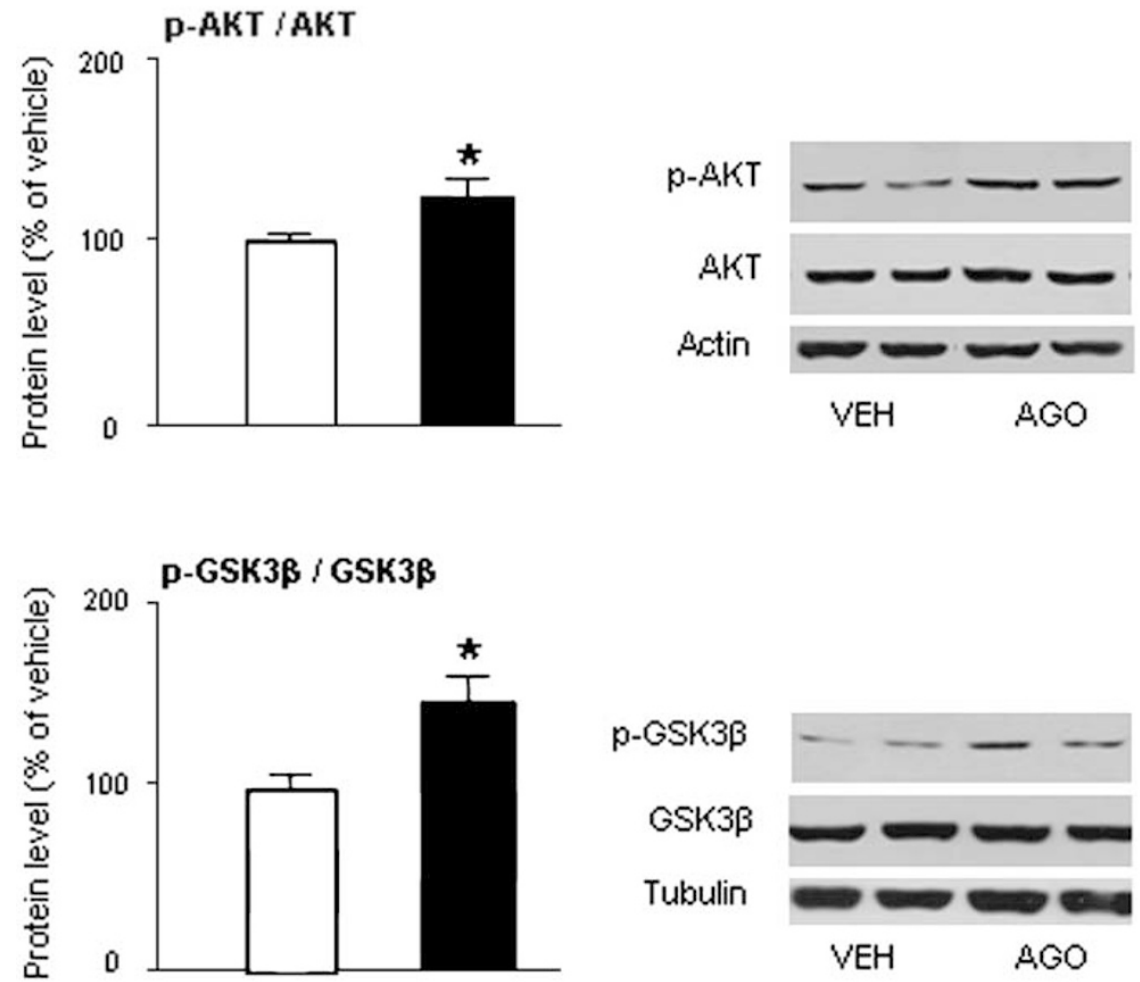

p-GSK3B

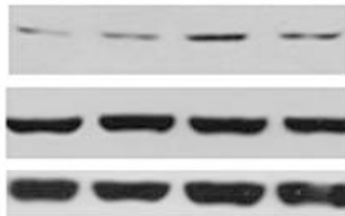

Tubulin

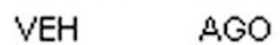

Figure 7 Effects of agomelatine on the ratio of levels of phosphorylated to total ERKI/2, AKT, and GSK3 $\beta$ protein. Hippocampal tissue was taken I6 $\mathrm{h}$ after the last vehicle or agomelatine treatment (2I days, $40 \mathrm{mg} / \mathrm{kg}$ i.p). Data are calculated as optical density (OD), expressed relative to the corresponding level of actin (AKT) or tubulin (ERKI/2 and GSK3 $\beta$ ), normalized to the corresponding total ERKI/2, AKT, or GSK3 $\beta$ level. Results are presented as mean \pm SEM percentage relative to vehicle levels (one-way ANOVA, * $p<0.05$; $* * p<0.01$ ) 
Table 2 Effects of 5- $\mathrm{HT}_{2 \mathrm{C}}$ Antagonists on Hippocampal Levels of Trophic Factors

\begin{tabular}{lccc}
\hline (pg/mg prot.) & BDNF & VEGF & IGF-I \\
\hline Vehicle & $21.7 \pm 1.0$ & $17.6 \pm 0.8$ & $91.3 \pm 4.1$ \\
SB242,084 & $19,8 \pm 1.4$ & $17.3 \pm 0.8$ & $96.4 \pm 3.4$ \\
SB243,213 & $17.7 \pm 1.1$ & $16.5 \pm 0.5$ & $88.1 \pm 3.2$ \\
\hline
\end{tabular}

Daily administrations of 5-HT2C antagonists or vehicle given for 21 days did not change the levels of trophic factors measured in the whole hippocampus. Results are means \pm SEM for 6 rats per group.

\section{p-ERK1/2 / ERK1/2}
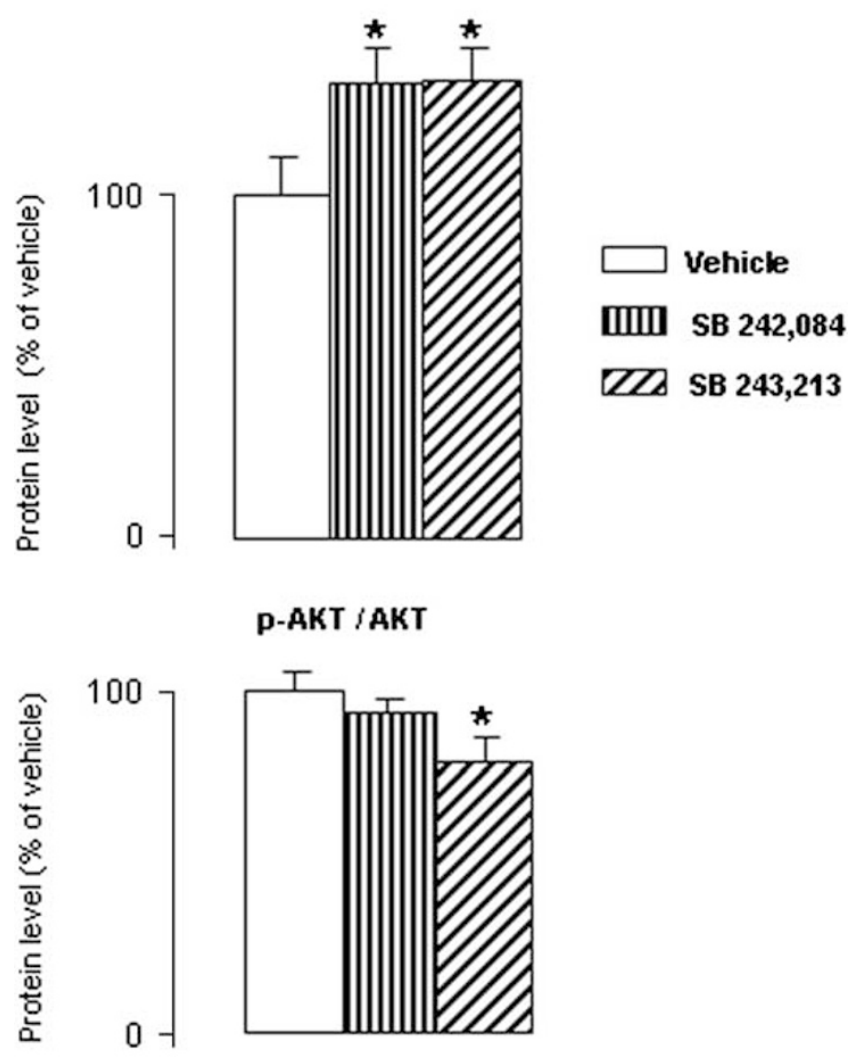

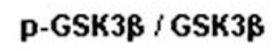

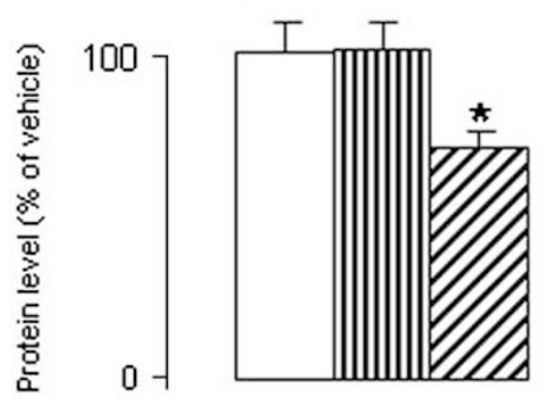

Figure 8 Effects of $5-\mathrm{HT}_{2} \mathrm{C}$ receptor antagonists on the ratio of levels of phosphorylated to total ERKI/2, AKT, and GSK3 $\beta$ protein. Hippocampal tissue was taken $16 \mathrm{~h}$ after the last vehicle, SB242084 or SB243213 treatment (2I days, $10 \mathrm{mg} / \mathrm{kg}$ i.p). Data are calculated as optical density $(O D)$, expressed relative to the corresponding level of actin (AKT) or tubulin (ERKI/2 and GSK3 $\beta$ ), normalized to the corresponding total ERKI/2, AKT, or GSK3 $\beta$ level. Results are presented as mean $\pm \mathrm{SEM}$ percentage relative to vehicle levels (one-way ANOVA, ${ }^{*} p<0.05$ ).
1997; Wood et al, 2001; Berg et al, 2006; Dekeyne et al, 2008; Chanrion et al, 2008; Millan MJ unpublished observations). The notion that inverse agonism is required for enhancing proliferation in the $\mathrm{VH}$ is supported by evidence that certain cerebral populations of $5-\mathrm{HT}_{2 \mathrm{C}}$ receptors are constitutively active (Berg et al, 2005), including sites tonically inhibitory, through GABAergic interneurones, to ascending dopaminergic or noradrenergic systems that are known to increase cell proliferation (Invernizzi et al, 2007; Hoglinger et al, 2004; Kulkarni et al, 2002; Millan et al, 2008; Aloyo et al, 2009). However, the interpretation of these data is also complicated by the fact that constitutive activity at $5-\mathrm{HT}_{2 \mathrm{C}}$ sites is regulated by mRNA editing that differs between brain regions; extensively edited $5-\mathrm{HT}_{2 \mathrm{C}}$ receptor isoforms being constitutively silent (Burns et al, 1997; Sanders-Bush et al, 2003). Notably, the cell population and receptor isoform controlling $\mathrm{VH}$ proliferation remain to be identified. Moreover, the possible neutral antagonist $v s$ inverse agonist actions of agomelatine are still under exploration and they will anyway be modified by its concomitant stimulation of melatonin receptors.

\section{Agomelatine Promotes Maturation and Survival in the Hippocampus: BDNF Involvement?}

How antidepressant influences the different phases of neurogenesis, and particularly maturation, has been poorly investigated, although it is a crucial step for the future integration and function of newly formed cells. A recent study showed that fluoxetine, known to enhance the proliferation of early progenitors cells in the adult brain (Encinas et al, 2006), also increases the maturation and survival of newborn neurons at 21 days post-BrdU (Wang et al, 2008). Here, we found that agomelatine appeared to induce an early acceleration of cell maturation at 8 days of development. This observation would benefit from direct comparisons with other classes of antidepressants, as it suggests that agomelatine precociously influences the immature neurons at a stage when they are synaptically silent but still respond to neurotransmitters, hormones, and trophic factors (Overstreet-Wadiche and Westbrook, 2006; Laplagne et al, 2006). Similarly, agomelatine increased the proportion of mature $v s$ immature neurons at 15 days of development, when the cells start to develop dendritic arborization, to extend axon terminals for establishing synapses with their targets, and to be integrated into hippocampal circuitry (Overstreet-Wadiche and Westbrook, 2006). As dentate granule cells born during early postnatal and adult periods have very similar behavior (Laplagne et al, 2006), we used postnatal hippocampal cultures to evaluate the effects of agomelatine on the dendritic development of granule cells, which has an important role in the functional integration of newly formed neurons into hippocampal networks (Overstreet-Wadiche and Westbrook, 2006). Likely resulting from changes in proliferation, maturation, and survival, agomelatine selectively increases the number of granule cells expressing Prox 1 and promotes their dendritic extension and arborization. In addition, in vivo agomelatine treatment also increased the survival of newborn cells at 15 and 21 days. This study further suggests that the early acceleration of maturation by agomelatine can induce an increase in the survival of newborn granule cells 
at a critical period of development. Interestingly, results from our previous study show that 8 days of agomelatine treatment does not affect cell proliferation (Banasr et al, 2006), reinforcing the view of distinct regulation of proliferation vs maturation or survival (Lee et al, 2006; Plumpe et al, 2006; Olson et al, 2006; Hernandez-Rabaza et al, 2006).

Consistent with this view, although the agomelatineinduced stimulation of cell proliferation may preferentially involve $5-\mathrm{HT}_{2 \mathrm{C}}$ receptor blockade, the increase in cell maturation and survival may be because of a joint action on melatonergic and $5-\mathrm{HT}_{2 \mathrm{C}}$ receptors. Indeed, the agomelatine-induced increase in cell survival was suppressed by a pretreatment with a melatonin receptor antagonist, whereas neither the $5-\mathrm{HT}_{2 \mathrm{C}}$ receptor antagonists nor melatonin alone mimicked this effect. The implication of melatonin agonist properties of agomelatine in this process is consistent with recent data showing a melatonin-induced increase of new granule cell maturation and survival in mice (Ramirez-Rodriguez et al, 2009). This neurotrophic role of melatonin was also suggested by in vitro data on viability and differentiation of neural stem cells (NSCs), which was associated to an increase in BDNF expression (Kong et al, 2008), even if in our experimental conditions melatonin alone does not modify cell survival. Indeed, we also found an increase in hippocampal BDNF level in agomelatine- and melatonin-treated rats, but for melatonin the increase is less pronounced. This difference in the influence of agomelatine and melatonine on BDNF levels may explain the lack of melatonin effects on cell survival in our experimental conditions and supports the need of a joint action between melatonergic agonist and $5-\mathrm{HT}_{2 \mathrm{C}}$ antagonist properties for agomelatine effects on cell survival. Indeed, BDNF has long been involved in maturation and survival (Sairanen et al, 2005; Bergami et al, 2008), although it has also been recently associated with the regulation of proliferation of hippocampal progenitors (Li et al, 2008). Our results are consistent with the general protective action of melatonin on neurons, potentially mediated by BDNF (Quiros et al, 2008; Manda et al, 2009; Imbesi et al, 2008). By contrast, melatonin does not modulate cell proliferation in mice (Ramirez-Rodriguez et al, 2009), and the contribution of 5$\mathrm{HT}_{2 \mathrm{C}}$ receptors in the agomelatine-induced increases in survival by BDNF level remains to be clarified, bearing in mind that a previous study performed under other conditions found that a chronic treatment for 2 weeks with S32006 elevated mRNA encoding hippocampal BDNF (Dekeyne et al, 2008). Here, the $5-\mathrm{HT}_{2 \mathrm{C}}$ receptor antagonists had no effect on BDNF, reinforcing the hypothesis that under the present experimental conditions, $5-\mathrm{HT}_{2 \mathrm{C}}$ receptors are preferentially involved in the regulation of cell proliferation rather than survival.

We also showed that agomelatine increases the phosphorylation of ERK1/2, AKT, and GSK3 $\beta$ known to transduce the effects of antidepressant agent and mood stabilizers on proliferation of hippocampal neural progenitors (Jiang et al, 2005; Wexler et al, 2008; Silva et al, 2008). The enhanced survival of new granule cells may also be related to the activation of MAPK (ERK1/2) and PI-3K signaling pathways, as previously shown in vitro (Almeida et al, 2005), and hippocampal NSCs can be protected from apoptosis by antidepressant-induced activation of BDNF and the MAPK pathway (Peng et al, 2008). Furthermore, inhibition of GSK3 $\beta$ by phosphorylation following lithiuminduced AKT activation has been shown to exert antiapoptotic effects (Jope and Bijur, 2002). These results are consistent with the neurotrophic-neuroprotective effects of mood stabilizers and antidepressants thought, at least partially, to be mediated by inhibition of GSK3 $\beta$ (Manji et al, 2003; Silva et al, 2008). Furthermore, indirect (upstream) regulation of GSK3 constitutes a new target for the control of affective disorders and highlights the role of neuroplasticity in their induction and treatment (Mathew et al, 2008; Jope and Roh, 2006; O'Brien and Klein, 2007; McClung and Nestler, 2008). Indeed, pharmacological inhibition of GSK3 $\beta$ activity was shown to produce antidepressant-like effects in rodents (Gould et al, 2004).

Melatonin has also been shown to activate the prosurvival AKT pathway and inhibit GSK $3 \beta$ activity in various brain regions (Lee et al, 2006; Tajes Orduña et al, 2009), which is consistent with its neuroprotective action and increases the ERK pathway (Kilic et al, 2005). By contrast, despite increases in ERK phosphorylation by SB243,213, we detected a significant negative regulation of GSK $3 \beta$, reinforcing the view that blockade of $5-\mathrm{HT}_{2 \mathrm{C}}$ receptors does not necessarily favor cell survival, and may preferentially enhance cell proliferation as suggested by the activation of ERK. It should be noted that this influence of $5-\mathrm{HT}_{2 \mathrm{C}}$ receptor blockade on ERK may not be direct, as Werry et al (2008) showed that activation of heterologously expressed $5-\mathrm{HT}_{2 \mathrm{C}}$ receptors in $\mathrm{CHO}$ cells recruits ERK. Although this difference between the current and previous work reflects the $5-\mathrm{HT}_{2 \mathrm{C}}$ receptor isoform, constitutive activity, the duration of exposure to drugs, the choice or ligand used and tissue differences that remains to be elucidated (Werry et al, 2008; Millan et al, 2008), our study clearly demonstrated a stimulating effect of the two $5-\mathrm{HT}_{2 \mathrm{C}}$ antagonists on ERK pathway, in vivo, on the rat hippocampus.

In conclusion, among the different phases of hippocampal neurogenesis stimulated by agomelatine, the rapid and early increase in maturation at a critical period of neuronal development likely influences the functional integration of newborn cells into hippocampal circuitry, an effect that may be related to the rapid clinical efficacy of agomelatine (Kasper and Lemoine, 2008). Although the links between hippocampal neurogenesis and psychiatric disorders are far to be elucidated (Vollmayr et al, 2007; Sahay and Hen, 2007; Fuchs, 2007; Eisch et al, 2008; Kempermann et al, 2008), a better understanding of the regulation of neurogenesis by antidepressants and how they influence distinct phases of progenitor cell development may yield insights into the physiological mechanisms that underlie antidepressant behavioral efficacy.

\section{DISCLOSURE/CONFLICT OF INTEREST}

This work was supported by CNRS and IRIS to A Daszuta and A Soumier. C Gabriel, E Mocaer, and MJ Millan are employed by Servier. The authors, M Banasr, S Lortet, F Masmejean, N Bernard, and L Kerkerian, declare that, except for income received from my primary employer, no financial support or compensation has been received from any individual or corporate entity over the past 3 years for 
research or professional service and there are no personal financial holdings that could be perceived as constituting a potential conflict of interest.

\section{REFERENCES}

Airan RD, Meltzer LA, Roy M, Gong Y, Chen H, Deisseroth K (2007). High-speed imaging reveals neurophysiological links to behavior in an animal model of depression. Science 317: 819-823.

Almeida RD, Manadas BJ, Melo CV, Gomes JR, Mendes CS, Graos MM et al (2005). Neuroprotection by BDNF against glutamateinduced apoptotic cell death is mediated by ERK and PI3-kinase pathways. Cell Death Differ 12: 1329-1343.

Aloyo VJ, Berg KA, Spampinato U, Clarke WP, Harvey JA (2009). Current status of inverse agonism at serotonin2A (5-HT2A) and 5-HT2C receptors. Pharmacol Ther 121: 160-173.

Altman J, Bayer SA (1990). Migration and distribution of two populations of hippocampal granule cell precursors during the perinatal and postnatal periods. J Comp Neurol 301: 365-381.

Alves SH, Pinheiro G, Motta V, Landeira-Fernandez J, Cruz AP (2004). Anxiogenic effects in the rat elevated plus-maze of 5-HT(2C) agonists into ventral but not dorsal hippocampus. Behav Pharmacol 15: 37-43.

Anderson MF, Aberg MA, Nilsson M, Eriksson PS (2002). Insulinlike growth factor-I and neurogenesis in the adult mammalian brain. Brain Res Dev Brain Res 134: 115-122.

Audinot V, Mailliet F, Lahaye-Brasseur C, Bonnaud A, Le Gall A, Amossé $C$ et al (2003). New selective ligands of human cloned melatonin $\mathrm{MT}_{1}$ and $\mathrm{MT}_{2}$ receptors. Naunyn-Schmiedeberg's Arch Pharmacol 367: 553-561.

Banasr M, Hery M, Printemps R, Daszuta A (2004). Serotonininduced increases in adult cell proliferation and neurogenesis are mediated through different and common 5-HT receptor subtypes in the dentate gyrus and the subventricular zone. Neuropsychopharmacology 29: 450-460.

Banasr M, Soumier A, Hery M, Mocaer E, Daszuta A (2006). Agomelatine, a new antidepressant, induces regional changes in hippocampal neurogenesis. Biol Psychiatry 59: 1087-1096.

Bannerman DM, Rawlins JN, McHugh SB, Deacon RM, Yee BK, Bast $\mathrm{T}$ et al (2004). Regional dissociations within the hippocampusmemory and anxiety. Neurosci Biobehav Rev 28: 273-283.

Berg KA, Harvey JA, Spampinato U, Clarke WP (2005). Physiological relevance of constitutive activity of 5-HT2A and 5-HT2C receptors. Trends Pharmacol Sci 26: 625-630.

Berg KA, Navailles S, Sanchez TA, Silva YM, Wood MD, Spampinato U et al (2006). Differential effects of 5-methyl-1[[2-[(2-methyl-3-pyridyl).oxyl]-5-pyridyl] carbamoyl]-6-trifluoro methylindone (SB 243213). on 5-hydroxytryptamine(2C). receptor-mediated responses. J Pharmacol Exp Ther 319: 260-268.

Bergami M, Rimondini R, Santi S, Blum R, Götz M, Canossa M (2008). Deletion of TrkB in adult progenitors alters newborn neuron integration into hippocampal circuits and increases anxiety-like behaviors. PNAS 105: 15570-15575.

Brandt MD, Jessberger S, Steiner B, Kronenberg G, Reuter K, Bick-Sander A et al (2003). Transient calretinin expression defines early postmitotic step of neuronal differentiation in adult hippocampal neurogenesis of mice. Mol Cell Neurosci 24: 603-613.

Burns CM, Chu H, Rueter SM, Hutchinson LK, Canton H, SandersBush E et al (1997). Regulation of serotonin-2C receptor Gprotein coupling by RNA editing. Nature 387: 303-308.

Chanrion B, Mannoury la Cour C, Gavarini S, Seimandi M, Vincent $\mathrm{L}$, Pujol JF et al (2008). Inverse agonist and neutral antagonist actions of antidepressants at recombinant and native 5hydroxytryptamine2C receptors: differential modulation of cell surface expression and signal transduction. Mol Pharmacol 73: 748-757.

Dekeyne A, Mannoury la Cour C, Gobert A, Brocco M, Lejeune F, Serres F et al (2008). S32006, a novel 5-HT2C receptor antagonist displaying broad-based antidepressant and anxiolytic properties in rodent models. Psychopharmacology (Berl) 199: 549-568.

Di Matteo V, Di Giovanni G, Di Mascio M, Esposito E (1999). SB 242084, a selective serotonin2C receptor antagonist, increases dopaminergic transmission in the mesolimbic system. Neuropharmacology 38: 1195-1205.

Dubocovich ML (2006). Agomelatine targets a range of major depressive disorder symptoms. Curr Opin Investig Drugs 7: 670-680.

Duman CH, Schlesinger L, Kodama M, Russell DS, Duman RS (2007). A role for MAP kinase signaling in behavioral models of depression and antidepressant treatment. Biol Psychiatry 61: 661-670.

Eisch AJ, Cameron HA, Encinas JM, Meltzer LA, Ming GL, Overstreet-Wadiche LS (2008). Adult neurogenesis, mental health, and mental illness: hope or hype? J Neurosci 28: 1178511791.

Encinas JM, Vaahtokari A, Enikolopov G (2006). Fluoxetine targets early progenitor cells in the adult brain. Proc Natl Acad Sci USA 103: 8233-8238.

Engin E, Treit D (2007). The role of hippocampus in anxiety: intracerebral infusion studies. Behav Pharmacol 18: 365-374.

Eriksson PS, Perfilieva E, Bjork-Eriksson T, Alborn AM, Nordborg C, Peterson DA et al (1998). Neurogenesis in the adult human hippocampus. Nat Med 4: 1313-1317.

Fuchs E (2007). Neurogenesis in the adult brain: is there an association with mental disorders? Eur Arch Psychiatry Clin Neurosci 257: 247-249.

Gascon E, Vutskits L, Kiss JZ (2007). Polysialic acid-neural cell adhesion molecule in brain plasticity: from synapses to integration of new neurons. Brain Res Rev 56: 101-118.

Gould TD, Einat H, Bhat R, Manji HK (2004). AR-A014418, a selective GSK-3 inhibitor, produces antidepressant-like effects in the forced swim test. Int J Neuropsychopharmacol 7: 387-390.

Hernandez-Rabaza V, Dominguez-Escriba L, Barcia JA, Rosel JF, Romero FJ, Garcia-Verdugo JM et al (2006). Binge administration of 3,4-methylenedioxymethamphetamine ('ecstasy') impairs the survival of neural precursors in adult rat dentate gyrus. Neuropharmacology 51: 967-973.

Hoglinger GU, Rizk P, Muriel MP, Duyckaerts C, Oertel WH, Caille I et al (2004). Dopamine depletion impairs precursor cell proliferation in Parkinson disease. Nat Neurosci 7: 726-735.

Holmes MC, Yau JL, French KL, Seckl JR (1995). The effect of adrenalectomy on 5-hydroxytryptamine and corticosteroid receptor subtype messenger RNA expression in rat hippocampus. Neuroscience 64: 327-337.

Invernizzi RW, Pierucci M, Calcagno E, Di Giovanni G, Di Matteo $\mathrm{V}$, Benigno A et al (2007). Selective activation of 5-HT(2C) receptors stimulates GABA-ergic function in the rat substantia nigra pars reticulata: a combined in vivo electrophysiological and neurochemical study. Neuroscience 144: 1523-1535.

Imbesi M, Uz T, Manev $\mathrm{H}$ (2008). Role of melatonin receptors in the effects of melatonin on BDNF and neuroprotection in mouse cerebellar neurons. J Neural Transm 115: 1495-1499.

Jayatissa MN, Bisgaard C, Tingstrom A, Papp M, Wiborg O (2006). Hippocampal cytogenesis correlates to escitalopram-mediated recovery in a chronic mild stress rat model of depression. Neuropsychopharmacology 31: 2395-2404.

Jiang W, Zhang Y, Xiao L, Van Cleemput J, Ji SP, Bai G et al (2005). Cannabinoids promote embryonic and adult hippocampus neurogenesis and produce anxiolytic- and antidepressant-like effects. J Clin Invest 115: 3104-3116.

Jin K, Zhu Y, Sun Y, Mao XO, Xie L, Greenberg DA (2002). Vascular endothelial growth factor (VEGF) stimulates neurogenesis 
in vitro and in vivo. Proc Natl Acad Sci USA 99: 11946-11950.

Jope RS, Bijur GN (2002). Mood stabilizers, glycogen synthase kinase3beta and cell survival. Mol Psychiatry 7(Suppl 1): S35-S45.

Jope RS, Roh MS (2006). Glycogen synthase kinase-3 (GSK3) in psychiatric diseases and therapeutic interventions. Curr Drug Targets 7: 1421-1434.

Kasper S, Lemoine P (2008). Comparative efficacy of the antidepressant agomelatine, venlafaxine and sertraline. Eur Neuropsychopharmacol 18(Suppl 4): S331.

Kempermann G, Krebs J, Fabel K (2008). The contribution of failing adult hippocampal neurogenesis to psychiatric disorders. Curr Opin Psychiatry 21: 290-295.

Kennedy SH, Emsley R (2006). Placebo-controlled trial of agomelatine in the treatment of major depressive disorder. Eur neuropsychopharmacol 16: 93-100.

Kennedy SH (2007). Agomelatine: an antidepressant with a novel mechanism of action. Future Neurol 2: 145-151.

Kennett GA, Wood MD, Bright F, Trail B, Riley G, Holland V et al (1997). SB 242084, a selective and brain penetrant 5-HT2C receptor antagonist. Neuropharmacology 36: 609-620.

Khawaja X, Xu J, Liang JJ, Barrett JE (2004). Proteomic analysis of protein changes developing in rat hippocampus after chronic antidepressant treatment: implications for depressive disorders and future therapies. J Neurosci Res 75: 451-460.

Kilic U, Kilic E, Reiter RJ, Bassetti CL, Hermann DM (2005). Signal transduction pathways involved in melatonin-induced neuroprotection after focal cerebral ischemia in mice. J Pineal Res 38: 67-71.

Kim SJ, Lee KJ, Shin YC, Choi SH, Do E, Kim S et al (2005). Stressinduced decrease of granule cell proliferation in adult rat hippocampus: assessment of granule cell proliferation using high doses of bromodeoxyuridine before and after restraint stress. Mol Cells 19: 74-80.

Kong X, Li X, Cai Z, Yang N, Liu Y, Shu J et al (2008). Melatonin regulates the viability and differentiation of rat midbrain neural stem cells. Cell Mol Neurobiol 28: 569-579.

Kulkarni VA, Jha S, Vaidya VA (2002). Depletion of norepinephrine decreases the proliferation, but does not influence the survival and differentiation, of granule cell progenitors in the adult rat hippocampus. Eur J Neurosci 16: 2008-2012.

Lagace DC, Yee JK, Bolanos CA, Eisch AJ (2006). Juvenile administration of methylphenidate attenuates adult hippocampal neurogenesis. Biol Psychiatry 60: 1121-1130.

Laplagne DA, Esposito MS, Piatti VC, Morgenstern NA, Zhao C, van Praag $\mathrm{H}$ et al (2006). Functional convergence of neurons generated in the developing and adult hippocampus. PLoS Biol 4: e409.

Lee KJ, Kim SJ, Kim SW, Choi SH, Shin YC, Park SH et al (2006). Chronic mild stress decreases survival, but not proliferation, of new-born cells in adult rat hippocampus. Exp Mol Med 38: 44-54.

Loo H, Hale A, D'haenen H (2002). Determination of the dose of agomelatine, a melatoninergic agonist and selective 5-HT(2C). antagonist, in the treatment of major depressive disorder: a placebo-controlled dose range study. Int Clin Psychopharmacol 17: 239-247.

Li Y, Luikart BW, Birnbaum S, Chen J, Kwon C, Kernie SG et al (2008). TrkB regulates hippocampal neurogenesis and governs sensitivity to antidepressive treatment. Neuron 59: 399-412.

Maccari S, Morley-Fletcher S, Mairesse J, Viltart O, Daszuta A, Soumier A et al (2005). Chronic treatment with agomelatine reversed the decrease in hippocampal cell neurogenesis and survival in prenatally stressed adult rats. Am Soc Neurosci 566: 8.

Malberg JE, Blendy JA (2005). Antidepressant action: to the nucleus and beyond. Trends Pharmacol Sci 26: 631-638.

Manda K, Ueno M, Anzai K (2009). Cranial irradiation-induced inhibition of neurogenesis in hippocampal dentate gyrus of adult mice: attenuation by melatonin pretreatment. J Pineal Res 46: 71-78.
Manji HK, Gottesman II, Gould TD (2003). Signal transduction and genes-to-behaviors pathways in psychiatric diseases. Sci STKE 2003207 pe49.

Mathew SJ, Manji HK, Charney DS (2008). Novel drugs and therapeutic targets for severe mood disorders. Neuropsychopharmacology 33: 2080-2092.

McClung CA, Nestler EJ (2008). Neuroplasticity mediated by altered gene expression. Neuropsychopharmacology 33: 3-17.

Meltzer LA, Yabaluri R, Deisseroth K (2005). A role for circuit homeostasis in adult neurogenesis. Trends Neurosci 28: 653-660.

Millan MJ (2005). Serotonin 5-HT2C receptors as a target for the treatment of depressive and anxious states: focus on novel therapeutic strategies. Therapie 60: 441-460.

Millan MJ, Brocco M, Gobert A, Dekeyne A (2005). Anxiolytic properties of agomelatine, an antidepressant with melatoninergic and serotonergic properties: role of 5-HT2C receptor blockade. Psychopharmacology (Berl) 177: 448-458.

Millan MJ, Gobert A, Lejeune F, Dekeyne A, Newman-Tancredi A, Pasteau $\mathrm{V}$ et al (2003). The novel melatonin agonist agomelatine (S20098). is an antagonist at 5-hydroxytryptamine2C receptors, blockade of which enhances the activity of frontocortical dopaminergic and adrenergic pathways. J Pharmacol Exp Ther 306: 954-964.

Millan MJ, Marin P, Bockaert J, la Cour CM (2008). Signaling at G-protein-coupled serotonin receptors: recent advances and future research directions. Trends Pharmacol Sci 29: 454-464.

Ming GL, Song H (2005). Adult neurogenesis in the mammalian central nervous system. Annu Rev Neurosci 28: 223-250.

Moser MB, Moser EI (1998). Functional differentiation in the hippocampus. Hippocampus 8: 608-619.

O’Brien WT, Klein PS (2007). Regulation of glycogen synthase kinase-3 in patients with affective disorders. Biol Psychiatry 61: 139-141.

Olie JP, Kasper S (2007). Efficacy of agomelatine, a MT1/MT2 receptor agonist with 5-HT2C antagonist properties, in major depressive disorder. Int J Neuropsychopharmacol 10: 661-673.

Olson AK, Eadie BD, Ernst C, Christie BR (2006). Environmental enrichment and voluntary exercise massively increase neurogenesis in the adult hippocampus via dissociable pathways. Hippocampus 16: 250-260.

Overstreet-Wadiche LS, Westbrook GL (2006). Functional maturation of adult-generated granule cells. Hippocampus 16: 208-215.

Papp M, Gruca P, Boyer PA, Mocaer E (2003). Effect of agomelatine in the chronic mild stress model of depression in the rat. Neuropsychopharmacology 28: 694-703.

Paxinos G, Watson C (1986). The rat brain in stereotaxic coordinates 2nd edn. Academic Press: San Diego.

Peng CH, Chiou SH, Chen SJ, Chou YC, Ku HH, Cheng CK et al (2008). Neuroprotection by Imipramine against lipopolysaccharide-induced apoptosis in hippocampus-derived neural stem cells mediated by activation of BDNF and the MAPK pathway. Eur Neuropsychopharmacol 18: 128-140.

Pleasure SJ, Collins AE, Lowenstein DH (2000). Unique expression patterns of cell fate molecules delineate sequential stages of dentate gyrus development. J Neurosci 20: 6095-6105.

Plumpe T, Ehninger D, Steiner B, Klempin F, Jessberger S, Brandt $M$ et al (2006). Variability of doublecortin-associated dendrite maturation in adult hippocampal neurogenesis is independent of the regulation of precursor cell proliferation. BMC Neurosci 7: 77.

Quiros I, Mayo JC, Garcia-Suarez O, Hevia D, Martin V, Rodriguez $C$ et al (2008). Melatonin prevents glucocorticoid inhibition of cell proliferation and toxicity in hippocampal cells by reducing glucocorticoid receptor nuclear translocation. J Steroid Biochem Mol Biol 110: 116-124. 
Ramirez-Rodriguez G, Klempin F, Babu H, Benitez-King G, Kempermann G (2009). Melatonin modulates cell survival of new neurons in the hippocampus of adult mice. Neuropsychopharm Published online 6 May 2009, doi:10.1038/npp.2009.46.

Sahay A, Hen R (2007). Adult hippocampal neurogenesis in depression. Nat Neurosci 10: 1110-1115.

Sairanen M, Lucas G, Ernfors P, Castren M, Castren E (2005). Brain-derived neurotrophic factor and antidepressant drugs have different but coordinated effects on neuronal turnover, proliferation, and survival in the adult dentate gyrus. J Neurosci 25: $1089-1094$.

Sanders-Bush E, Fentress H, Hazelwood L (2003). Serotonin 5-HT2 receptors: molecular and genomic diversity. Mol Interv 3: 319-330.

Santarelli L, Saxe M, Gross C, Surget A, Battaglia F, Dulawa S et al (2003). Requirement of hippocampal neurogenesis for the behavioral effects of antidepressants. Science 301: 805-809.

Schechter LE, Ring RH, Beyer CE, Hughes ZA, Khawaja X, Malberg $\mathrm{JE}$ et al (2005). Innovative approaches for the development of antidepressant drugs: current and future strategies. NeuroRx 2: 590-611.

Schmidt HD, Duman RS (2007). The role of neurotrophic factors in adult hippocampal neurogenesis, antidepressant treatments and animal models of depressive-like behavior. Behav Pharmacol 18: $391-418$

Seki T (2002). Expression patterns of immature neuronal markers PSA-NCAM, CRMP-4 and NeuroD in the hippocampus of young adult and aged rodents. J Neurosci Res 70: 327-334.

Silva R, Mesquita AR, Bessa J, Sousa JC, Sotiropoulos I, Leao P et al (2008). Lithium blocks stress-induced changes in depressive-like behavior and hippocampal cell fate: the role of glycogensynthase-kinase-3beta. Neuroscience 152: 656-669.

Snyder JS, Radik R, Wojtowicz JM, Cameron HA (2008). Anatomical gradients of adult neurogenesis and activity: young neurons in the ventral dentate gyrus are activated by water maze training. Hippocampus 19: 360-370 e-pub ahead of print.

Song HJ, Stevens CF, Gage FH (2002). Neural stem cells from adult hippocampus develop essential properties of functional CNS neurons. Nat Neurosci 5: 438-445.
Surget A, Saxe M, Leman S, Ibarguen-Vargas Y, Chalon S, Griebel $\mathrm{G}$ et al (2008). Drug-dependent requirement of hippocampal neurogenesis in a model of depression and of antidepressant reversal. Biol Psychiatry 64: 293-301.

Tajes Orduña M, Pelegrí Gabalda C, Vilaplana Hortensi J, Pallàs Lliberia M, Camins Espuny A (2009). An evaluation of the neuroprotective effects of melatonin in an in vitro experimental model of age-induced neuronal apoptosis. J Pineal Res 46: 262-267.

Vollmayr B, Mahlstedt MM, Henn FA (2007). Neurogenesis and depression: what animal models tell us about the link. Eur Arch Psychiatry Clin Neurosci 257: 300-303.

Wang JW, David DJ, Monckton JE, Battaglia F, Hen R (2008). Chronic fluoxetine stimulates maturation and synaptic plasticity of adult-born hippocampal granule cells. J Neurosci 28: $1374-1384$.

Warner-Schmidt JL, Duman RS (2006). Hippocampal neurogenesis: opposing effects of stress and antidepressant treatment. Hippocampus 16: 239-249.

Warner-Schmidt JL, Duman RS (2007). VEGF is an essential mediator of the neurogenic and behavioral actions of antidepressants. Proc Natl Acad Sci USA 104: 4647-4652.

Weibel L, Rettori MC, Lesieur D, Delagrange P, Renard P, Van Reeth O (1999). A single oral dose of S 22153, a melatonin antagonist, blocks the phase advancing effects of melatonin in C3H mice. Brain Res 829: 160-166.

Werry TD, Stewart GD, Crouch MF, Watts A, Sexton PM, Christopoulos A (2008). Pharmacology of 5HT(2C) receptormediated ERK1/2 phosphorylation: agonist-specific activation pathways and the impact of RNA editing. Biochem Pharmacol 76: 1276-1287.

Wexler EM, Geschwind DH, Palmer TD (2008). Lithium regulates adult hippocampal progenitor development through canonical Wnt pathway activation. Mol Psychiatry 13: 285-292.

Wood MD, Reavill C, Trail B, Wilson A, Stean T, Kennett GA et al (2001). SB-243213; a selective 5-HT2C receptor inverse agonist with improved anxiolytic profile: lack of tolerance and withdrawal anxiety. Neuropharmacology 41: 186-199. 